\title{
ランチョンセミナー 3
}

\section{自己免疫疾患と $\mathrm{T}$ 細胞}

\author{
東京大学大学院内科学専攻アレルギーリウマチ学 \\ 山本一彦
}

自己免疫疾患には臓器特異的自己免疫疾患と全身性自己免疫疾患がある．前者は甲状腺炎や多発性硬化症に代 表されるもので, 免疫寛容（トレランス）になっているはずの臟器固有の自己の抗原に対して何らかの原因でト レランスが破綻して，その自己抗原に特異的なT細胞や自己抗体が出現し，その結果病態が形成されるものであ る.一方，膠原病といわれる疾患群は全身性自己免疫疾患とされている．翏原病で見いだされる自己抗体の標的 は全身の細胞が持っている核内分子や細胞質分子であり, 現在のところ, 自己抗体に対する免疫異常と種々の病 態とが一元的に理解できていない.

今回は, 慢性関節リウマチ, 全身性エリテマトーデスなどにおけるT細胞の役割に対するいくつかの考え方を 紹介しながら, 我々の確立した $\mathrm{T}$ 細胞クローンを検出するシステムでのデータとともに，自己免疫疾患における T細胞の病因論的役割を議論したい. 